DOI: $10.17516 / 1997-1370-0473$

УДК 159.922.762:616.899

\title{
Studying and Evaluating Emotional and Personal Tendencis and Behavioural Patterns of Emotional Response of Primary School Pupils with Impaired Intellectual Development
}

\author{
Natalia Yu. Verkhoturova* and Yaroslavna V. Bardetskaya* \\ Krasnoyarsk State Pedagogical University \\ named after V.P. Astafiev \\ Krasnoyarsk, Russian Federation
}

Received 03.07.2019, received in revised form 12.08.2019, accepted 26.08.2019

\begin{abstract}
The article raises the insufficiently studied, yet the crucial problem of the need for timely study and evaluation of emotional and personal tendencies and behavioural patterns of emotional response of primary school pupils with impaired intellectual development. The key problems related to the improvement of these pupils' socialization and social adaptation in the modern society cannot be solved without studying the emotional regulation of their behaviour and correcting possible swerves. The studied schoolchildren are characterized by significant lagging in the development of emotional response, a narrow range of feelings, frequent incompliance of emotional reactions with external influences as regards strength, intensity and details of these reactions, limited interpretation of sensory material, which in aggregate lead to inadequate perception of other people's emotional reactions and not always adequate and differentiated expression of their own emotional responses in socially acceptable ways. All these tendencies provoke difficulties for pupils' with impaired intellectual development in their relationships between themselves and with surrounding adults; create serious barriers for their training and education; contribute to different deviations in behaviour; lead to travails of social adaptation and socialization.

The article describes the organization of the carried out research, presents the main components, technological parameters, stages of the study of emotional and personal tendencies and behavioural repertoire of emotional responses of primary school pupils with intellectual development disorders. The model used in the research consists of consistently implemented diagnostic procedures aimed at studying and evaluating dominating emotional reactions, expressive reactions; at regulating emotional responses; as well as at studying and evaluating the cognitive-perceptual dimension of emotional responses of primary school pupils with impaired intellectual development.

On the basis of the ongoing research, the authors identified specific features of emotional and personal tendencies and behavioural patterns of emotional response of primary school pupils with impaired intellectual development, which is not only possible, but
\end{abstract}

\footnotetext{
(C) Siberian Federal University. All rights reserved

* Corresponding author E-mail address: verhotyrovs@mail.ru ORCID: 0000-0003-2296-7397 (Verkhoturova); 0000-0002-5795-1371 (Bardetskaya)
} 
also necessary to undergo psychological and pedagogical correction in order to improve the processes of socialization and integration of these pupils in modern society.

Keywords: emotional response, emotional reactions, emotional-personal tendencies, behavioural patterns, components of emotional response, pupils with impaired intellectual development.

Research area: correctional psychology.

Citation: Verkhoturova, N. Yu., Bardetskaya, Ya.V. (2022). Studying and evaluating emotional and personal tendencis and behavioural patterns of emotional response of primary school pupils with impaired intellectual development. J. Sib. Fed. Univ. Humanit. Soc. Sci., 15(3), 406-416. DOI: 10.17516/19971370-0473.

\section{Statement of the problem and objectives of the study}

Analysis of the modern research results has shown that socialization problems, which students with impaired intellectual development face, are determined not only by a congenital defect, but also, to a greater extent, by their insufficient skills in regulating their behaviour and activities in the social environment. The lack of timely diagnostic and psychocorrectional care gives rise to a series of subsequent secondary disorders, including the emotional and personal ones, difficulties in social interaction with others, manifested later in the unsuccessful school life and social maladjustment of this category of schoolchildren.

Emotional sphere performs essential functions, connected with the reflection of the world around, with adaptation to its constantly changing conditions, the same goes for schoolchildren with mental disabilities. Due to abnormal intellectual regulation, the emotional reactions of children with impaired intellectual development do not always correspond to external influences in their strength, dynamics and expression. Violations of the adequacy of emotional reactions can be observed even at an early age. By the time of schooling these violations are not only preserved, but also aggravated, acquiring the features of a pathology; they incite difficulties in relationships with others, create serious barriers for the education and upbringing of this category of schoolchildren, making their problems of socialization even more serious.
Primary school pupils with intellectual disabilities are characterized by a pronounced lagging behind from other students in terms of the development of emotions. They show undifferentiated emotional state and instability of emotional response, limited range of feelings, the extreme expression of joy, grief, anger and happiness. The emotional response of younger students with impaired intellectual development is followed by inertia, manifested in the difficulties of changing one emotional reaction to another, or, in contrast, lability. The expression of even basic emotions, like emotional response, emotional fireworks or outburst (affect) is often accompanied by poor concreteness of emotional response (complete or partial lack of understanding of the causes of emotional experience); limited ability of these schoolchildren to express emotional reactions in socially acceptable ways.

In most cases, the specific features of emotional and personal tendencies and the behavioural repertoire of emotional responses lead to an acute negative reaction of surrounding people and the dominance of punishments in the methods of upbringing these children. Very often such a child is in conflict with the generally accepted norms of behaviour and the requirements of adults, destroying the already unstable system of their own relations with the surrounding social reality. The occurring hardships cause an increase in emotional tension, anxiety, negativism and hostility; the development of misunderstanding and proneness to conflict, which further exacerbates and intensifies deviations in the 
emotional-personal and behavioural sphere, and, in particular, induces the aggressive behaviour of such students.

Analysis of the modern literature has proved scarce theoretical coverage of this problem in special psychology journals. The phenomenon of emotional response of students with impaired intellectual development has not been studied thoroughly, which is confirmed by the lack of comprehensive scientific, theoretical and empirical research on the identified problem. In the literature studied there is only generalized information about the specific features of the emotional behaviour regulation of this category of schoolchildren (Lebedinsky, 2003; Lubovsky, 2009; Petrova, Beliakova, 2002; Rubinstein, 1986, etc.). Much less works are devoted to the problem of the empirical study of individual emotional reactions of students with impaired intellectual development, their theoretical understanding in the context of the analysis of the internal mental regulation and control over their behaviour and activities (see, for example: Agavelian, Agavelian, 1997; Verkhoturova, 2012; Pleshakova, Nugaeva, 2011; Semenova, 2008; Shapovalova, 2005, etc.).

There is not enough coverage of the expression, structure and mechanisms of emotional response of students with impaired intellectual development, changes and refinement of their emotional responses from the standpoint of age and gender differences, but, what is more important, the issues of the development of effective programs for comprehensive diagnostic assessment of emotional response management skills and the relevant correction, which is highly necessary for the studied category of schoolchildren.

The existing peculiarity of emotional and personal tendencies and behavioural patterns of emotional response of primary school pupils with intellectual disabilities leads to additional difficulties in their training and education, barriers to communicative interaction, difficulties in social adaptation. This, coupled with incomplete development of psychological approaches to timely diagnostic and correctional work on the formation of skills of these children to manage their emotional response, determined the relevance of the problem we raised and prompted us to start the present study.

\section{Methodology (materials and methods)}

Based on the previously developed by us concept of managing emotional responses in primary school pupils with impaired intellectual development, we created, theoretically substantiated and introduced into school education a technological model for studying and evaluating emotional and personal tendencies and behavioural patterns of emotional response of the studied schoolchildren.

The experimental study was conducted in educational institutions for students and pupils with disabilities. The study involved teachers and psychologists of these educational institutions, as well as students with mild intellectual disabilities. The experimental groups included only children with a clinical diagnosis F70 "Mild mental retardation". The experiment encompassed several groups within the primary school age (8-9, 10-11 years old).

In organizing the study, we took as point of departure the understanding of the emotional response as a complex multidimensional and multicomponent structural-hierarchical phenomenon, an objective study and monitoring of whose development requires a conceptual theoretical and methodological work on a comprehensive assessment system, involving defining technological parameters, criteria and indicators of all components of this system structure.

For the study and evaluation of emotional and personal tendencies, as well as behavioural patterns of emotional response of primary school pupils with intellectual disability, we singled out the following main components:

The impressive component, which is the obligatory aspect of the emotional response research model, which means the assessment of understanding and differentiation of emotional reactions; understanding their causation, connection of emotional reaction with the concrete subject;

The expressive component, which is the obligatory aspect of the emotional response research model, which implicates the assessment of mimic expressiveness; enrichment of emo- 
tional reactions with optimal means for external expression of these reactions.

The next level of the research model is a set of particular facets (aspects) of emotional response, revealing specific details of emotional and personal tendencies and behavioural patterns of emotional response of primary school pupils with intellectual development disorders. This level comprises:

The communicative component, which is the ability to receive and transmit emotional information using the means to express emotional response in public;

The interactive component, which is the ability to respond emotionally; empathize and sympathize; interact effectively;

The perceptual component, which consists of the ability to perceive and reproduce emotional information integrally, structurally and objectively on the basis of means to express emotional response in public;

The cognitive component, which is the ability to understand the substantive emotional reactions based on the skill to distinguish and differentiate these reactions, to use the means of emotional response;

The regulatory component, which is the ability to plan and control the different emotional response models using the means to express them in public.

In the process of this study realization, we defined and described the substantive content of the technological parameters of studying and evaluating emotional and personal tendencies and behavioural repertoire of emotional response of primary school pupils with impaired intellectual development. Among these parameters we pinpointed the following: the duration of the emotional response, which is a qualitative and / or quantitative characteristic, expressing the length of the emotional response over time; the concreteness of the emotional response, which is a qualitative and/or quantitative characteristic that conveys a degree of understanding and comprehension of the emotional reactions (states) experienced and their causes; the intensity of emotional response, which is a qualitative and / or quantitative characteristic, denominating the degree of strength, tension, intensity of emotional response.
In order to do the research on the study and assessment of emotional and personal tendencies and behavioural patterns of emotional responses of primary school pupils with impaired intellectual development, we selected various emotional responses differing in their modality: "joy", "fear", "anger", "anxiety", "offense" and "aggression".

The experimental study included several diagnostic stages.

1. Studying and evaluating the emotional reactions that dominate in students' behaviour. Experimental research suggested studying the emotional reactions prevailing in the behaviour of pupils with impaired intellectual development and an assessment of their emotional and personal tendencies of emotional response. The results obtained testified not only to the dominant emotional reactions, but also indicated the level of their compliance with and adequacy to the emotional stimuli.

2. The study and evaluation of meaningful expressiveness and regulation of emotional response. Our experimental research was aimed at exploring the meaningful expressiveness of emotional reactions of students with impaired intellectual development and assessing their condition by the following parameters: concreteness, objectivity, duration, and then the extent to which they comply with the standards and rules of behaviour adopted in society.

3. The study and evaluation of the cognitive-perceptual aspects of the emotional response. The target of this diagnostic procedure incorporated the study and assessment of the skills of students with impaired intellectual development to perceive and reproduce emotional information objectively; to distinguish emotional reactions using the analysis and selection of essential traits and constituent elements of meaningful expression; to correlate emotional reactions with the substantive content; to name their sign attribution (modality).

\section{Results and discussion}

At the first stage of the study we collected information about the interviewees, which implied work in two directions: 1) an analysis of 
psychological, medical and pedagogical documentation and 2) a survey of participants in the experiment. Special questionnaires were developed for students with intellectual disabilities and teachers working in these educational institutions.

In respect to a survey of primary school pupils with intellectual disability, it was found that most of the respondents in the boys groups and girls groups aged 8-9 and 10-11 years have difficulty in determining their emotional state; they do not know the names of many emotional reactions and their causes. In both age groups of test pupils, we pointed out a general trend in analyzing the causes of emotional reactions. The overwhelming majority of primary school pupils replace the definition of the causes of emotional experience by listing the child's actions at the time of the emotional reactions experienced. The respondents gave the following answers "I play", "I trundle the car", "I watch cartoons", "I walk" to the questions "Do you ever feel happy?", "Do you ever feel sad?" and alike. The vocabulary of pupils of both age and gender groups does not have names of many emotional reactions. Emo- tional reaction "joy" is substituted by "happy", "good"; "fear" is changed for a simpler one reaction "scared", "I am afraid".

Analysis of the results of the survey of teachers showed that all the participants of both age and gender groups rarely realize their emotional reactions and practically do not correlate them with the context of the situation. There are low indicators of the adequacy of emotional reactions to external influences as regards the content, intensity and duration of these reactions. All interviewees experienced difficulties in controlling emotional reactions both during classes and in normal situations of communication with peers.

The information obtained was supplemented by the results of observations and analysis of initial conversations with primary school pupils with intellectual development disorders and their teachers. According to the results of this stage of the study, it was concluded that the indicators prevailing for all interviewees were deviations in behaviour, which was expressed in disturbed interaction with adults and peers, in the apparent aggressive tendencies, impulsiveness, proneness to conflict and irascibility (Table 1)

Table 1. Results of the analysis of psychological and pedagogical documentation of primary school pupils with impaired intellectual development. Comparative data

\begin{tabular}{|c|c|c|c|c|c|c|c|c|}
\hline \multirow{4}{*}{ Parameters } & \multicolumn{8}{|c|}{ Age groups } \\
\hline & \multicolumn{4}{|c|}{ Boys } & \multicolumn{4}{|c|}{ Girls } \\
\hline & \multicolumn{2}{|c|}{$8-9$} & \multicolumn{2}{|c|}{$10-11$} & \multicolumn{2}{|c|}{$8-9$} & \multicolumn{2}{|c|}{$10-11$} \\
\hline & abs.* & $\%$ & abs. & $\%$ & abs. & $\%$ & abs. & $\%$ \\
\hline Behaviour deviations & 26 & 74.3 & 28 & 77.8 & 24 & 66.7 & 26 & 70.3 \\
\hline $\begin{array}{l}\text { Disturbed communication with adults and } \\
\text { peers }\end{array}$ & 27 & 77.2 & 29 & 80.6 & 25 & 69.5 & 25 & 67.6 \\
\hline Proneness to conflict & 23 & 65.8 & 26 & 72.3 & 18 & 50.0 & 22 & 59.5 \\
\hline Aggressive tendencies & 25 & 71.5 & 27 & 75.0 & 22 & 61.2 & 25 & 67.6 \\
\hline Affective manifestations & 24 & 68.6 & 25 & 69.5 & 24 & 66.7 & 24 & 64.9 \\
\hline Impulsive behaviour & 6 & 74.3 & 26 & 72.3 & 24 & 66.7 & 24 & 64.9 \\
\hline Negativism & 20 & 57.2 & 21 & 58.4 & 15 & 41.7 & 15 & 40.6 \\
\hline Vengefulness & 13 & 37.2 & 15 & 41.7 & 12 & 33.4 & 13 & 35.2 \\
\hline Intolerance to the opinions of others & 21 & 60.0 & 21 & 58.4 & 18 & 50.0 & 18 & 48.7 \\
\hline Irascibility & 22 & 62.9 & 26 & 72.3 & 20 & 55.6 & 24 & 64.9 \\
\hline Assertive behaviour & 12 & 34.3 & 17 & 47.3 & 12 & 33.4 & 15 & 40.6 \\
\hline
\end{tabular}


Natalia Yu. Verkhoturova, Yaroslavna V. Bardetskaya. Studying and Evaluating Emotional and Personal Tendencis...

Table 2. Indicators of emotional manifestations of primary school pupils with impaired intellectual development, according to the HTP method (\%)

\begin{tabular}{|l|c|c|c|c|}
\hline \multirow{2}{*}{\multicolumn{2}{c|}{ Symptom complexes }} & \multicolumn{4}{|c|}{ Age groups } \\
\cline { 2 - 5 } & \multicolumn{2}{|c|}{ Girls } & \multicolumn{2}{c|}{ Boys } \\
\cline { 2 - 5 } & $\begin{array}{c}8-9 \text { years } \\
(\mathrm{n}=36)\end{array}$ & $\begin{array}{c}10-11 \text { years } \\
(\mathrm{n}=37)\end{array}$ & $\begin{array}{c}8-9 \text { years } \\
(\mathrm{n}=35)\end{array}$ & $\begin{array}{c}10-11 \text { years } \\
(\mathrm{n}=36)\end{array}$ \\
\hline Insecurity & 41.7 & 40.6 & 34.3 & 33.4 \\
\hline Anxiousness & 47.3 & 51.4 & 42.9 & 44.5 \\
\hline Agressiveness & 63.9 & 70.3 & 71.5 & 77.8 \\
\hline Asociality & 41.7 & 40.6 & 28.6 & 30.6 \\
\hline Hostility & 58.4 & 70.3 & 68.6 & 77.8 \\
\hline $\begin{array}{l}\text { Proneness to conflict } \\
\text { (frustration) }\end{array}$ & 50.0 & 67.6 & 65.8 & 80.6 \\
\hline Difficulties in communication & 63.9 & 75.7 & 80.0 & 83.4 \\
\hline
\end{tabular}

In addition, the analysis of the data got allowed us to mark a tendency of increased severity of the considered parameters when the children grow up, which indicates the need for timely diagnosis and taking measures to correct the spotted weak points.

The use of the projective drawing technique "House - Tree - Person" (hereinafter referred to as HTP) by R.C. Burns and S. H. Kaufman (modified by R.F. Beliauskaite) made it possible to obtain information about the dominant emotional reactions of primary school pupils with impaired intellectual development, their aggressiveness, hostility, anxiousness, proneness to conflict and other traits (Table 2).

As follows from the data in the table, all pupils, who participated in the study, demonstrated that out of the seven symptom complexes the most frequent and pronounced are the following: aggressiveness, hostility, anxiousness, proneness to conflict and difficulties in communication.

At the second stage of the study, we investigated and evaluated meaningful expressiveness and regulation of the emotional response of these very primary school pupils with impaired intellectual development.

Within the framework of this stage we used the standardized "Method of monitoring the emotional expression of a child" introduced by J. Schwanzara. The evaluation scale included: a list of emotional reactions, modified according to the aims of our study, besides, the parameters "concreteness" and "duration" were added to the parameter "intensity". All emotional reactions were differentiated in agreement with the selected by us criteria and are presented in individual "Profiles of emotional response".

As a result of the study, it was found that all participants of both age and gender groups showed extremely high indicators of intensity of aggressiveness, violence, cheerfulness and anger. Apart from that, there were identified age and gender differences in the intensity of emotional expression. It was discovered that the level of intensity of violence, aggressiveness, cheerfulness and anger in the group of boys aged 10-11 years has a striking tendency to increase with age. Indicators of aggressiveness and cheerfulness turned out to be higher by $10.2 \%$, violence - by $10.5 \%$, anger - by $10.4 \%$ than in the group of boys aged $8-9$ years. Somewhat different situation was observed in the group of girls aged 10-11 years, where the intensity of violence was lower by $3.0 \%$, anger - by $0.9 \%$, cheerfulness - by $3.7 \%$ than in the group of girls aged 8-9 years. The lowest intensity indicator of empathy in was recorded in all the groups.

The minimum concrete correlation of emotional reactions of all participants refers to the emotional manifestations of susceptibility 
to offense, violence, aggressiveness, anxiousness and empathy. Primary schoolchildren with intellectual disabilities have difficulty understanding and controlling their emotional reactions; they do not correlate external influences with their emotional reactions. The highest indicators of awareness of emotional reactions among boys and girls of all age groups were noted in relation to fear, joy and anger.

Analysis of the results of the emotional reactions study (with the main parameter being duration) proved that all the participants had extremely excessive indicators in the expression of aggressiveness, anger and joy. The lowest level of duration in all gender groups concerned expression of empathy and anxiousness. Furthermore, there were identified age and gender differences as regards the duration indicator of the emotional responses "aggressiveness" and "anger". In the groups of boys aged 8-9 and 10-11 years, the expression of these emotional reactions lasted longer than those reactions in the groups of girls of the same age.

The third stage of the study was focused on studying and assessing the cognitiveperceptual implications of the emotional response in primary school pupils with impaired intellectual development. To complete this stage of the study, we used the technique "Examiming the understanding of emotional reactions depicted in the picture" by G. A. Uruntaeva, Yu.A. Afon'kina. We adapted the procedures of the methodology, simplified the instruction, selected the material with a pictorial display of emotional reactions and series of pictures illustrating certain situations, added one methodological stage was and reduced the number of tasks. Upon completion of the adaptation, we conducted a pilot experiment, which showed sufficient validity of this methodology. The experimental work was carried out in two directions: 1) the study of emotional reactions and assessment of their understanding, and 2) their subsequent verbalization.

In each direction, the interviewees were offered two series of tasks. In the first series, we determined the current level of children's development; in the second series we evaluated their potential opportunities. To study their emotional reactions, evaluate their understanding and name them, students were offered sheets with graphic image on the slides. These images showed a sort of face expressing different basic emotional reactions. In the second series of tasks the children looked at pictures which showed different life situations and had hidden clues. The display of these pictures was accompanied by a conversation between the experimenter and the child, which included finding out the signs that the child relies on in determining the emotional reaction and its further verbalization. During the conversation, the researcher determined how well the pupils understood the meaning of the events depicted in the pictures, and how adequately they correlated the context of the situation with the character's emotional response.

A comparative analysis of the results of the tasks done by both age and gender groups during two stages of this methodology showed that the participants were more successful in completing tasks aimed at studying the understanding of emotional reactions and their differentiation than the tasks aimed at verbalization of these reactions. The second series of tasks, namely working with pictures of different life situations and leading questions from the experimenter, improved the results of all children.

The results of the tasks from the first stage of the methodology showed that all boys and girls aged 8-9 and 10-11 years experience the greatest difficulties in understanding and differentiating the emotional reactions of anger, anxiousness and aggression. The most recognizable for all the children were the emotional reactions of joy and fear, whereas offence was the least recognized.

Particular difficulties in understanding and differentiating the emotional reactions of anger, aggression and anxiousness were observed in all groups of primary school pupils with impaired intellectual development. Groups of boys and girls aged 8-9 years could not correctly indicate any of the abovementioned emotional reactions when doing the tasks from the first and second series. Though groups of boys and girls aged 10-11 
years showed somewhat higher results, they experienced grave difficulties in the differentiation of emotional reactions. The conversation with leading questions did not produce the desired results

The second stage of this methodology realization was directed at studying the understanding and verbalization of emotional reactions of primary school pupils with impaired intellectual development. Analyzing the results of the second stage of the methodology, we found that among all the emotional reactions presented on slides, pupils aged 10-11 years and less often pupils aged 8-9 years most frequently identified joy, fear and offense. The names of other emotional reactions ("anger", "anxiety" and "aggression") were unrecognised by all the children while they did both series of tasks. Along with this, it was revealed that the main reason for the difficulties in all the series of tasks for all age and gender groups was the lack of knowledge about the main essential signs of the external expression of emotional reactions and their names.

\section{Conclusion}

Having made a comparative analysis of the results of the study in all age and gender groups, we should admit that pupils with impaired intellectual development show higher rates of understanding of such emotional reactions as joy, fear and anger when they grow up, yet, they still have difficulties in differentiation and verbalization of these reactions. Difficulties in understanding, differentiating and verbalizing the emotional reactions of offence, aggression and anxiousness were observed in all age groups of students with impaired intellectual development

Our study on the study and assessment of the emotional and personal tendencies and the behavioural repertoire of emotional responses of primary school pupils with impaired intellectual development made it possible to draw the conclusion that all the participants have specific aberrations at the level of basic behavioural components: intensity, concreteness, duration. The pupils showed these aberrations due to the absence of adequate, accurate and complete understanding of the causes of emotional experience or even due to the partial understanding of the causes of emotional reactions. The aberrations were also caused by the incompliance of emotional reactions to external influences as regards their strength and duration; by difficulties in understanding, differentiating and verbalizing emotional reactions. These violations entailed deviations in behaviour, which was expressed in encumbered of interaction with adults and peers, in the apparent aggressive tendencies, impulsiveness, proneness to conflict and irascibility.

In the course of an experimental study, we identified some gender characteristics in the realization of emotional and personal tendencies and behavioural repertoire of emotional reaction of pupils with impaired intellectual development in terms of the intensity and duration of emotional reactions. At the same time, there is no difference in terms of the subject correlation of visible peculiarities in the emotional response of boys and girls.

\section{References}

Agavelian, M.G., Agavelian, P.O. (1997). Diagnostika opoznaniia neverbal'nykh kommunikativnykh znakov i obuchenie ikh ispol'zovaniiu kak faktor gumanizatsii obrazovaniia detei s intellektual'nymi nedostatkami [Diagnosis of identification of non-verbal communication signs and teaching how to use them as a factor of humanization of education of children with intellectual disabilities]. In Vserossiiskaia nauchnoprakticheskaia konferentsiia "Gumanizatsiia obrazovaniia - imperativ XXI veka" [All-Russian scientificpractical conference "The humanization of education - the imperative of the $21^{\text {st }}$ century"], 139-141.

Bardetskaya, Y.V., Verkhoturova, N. Yu., Abdulkin, V.V. (2016). Correlates of temperamental features, adaptive responses and conditions in junior schoolchildren. In SGEM International Multidisciplinary Scientific Conference on Social sciences and Arts, 1 (1), 117-122.

Beliauskaite R.F. (2003). Risunochnye proby kak sredstvo diagnostiki razvitiya lichnosti rebyonka [Picturesque tests as a means of diagnosing the development of a child's personality]. In Psihologicheskoe 
obsledovanie detej doshkol'nogo - mladshego shkol'nogo vozrasta: Teksty i metodicheskoe posobie [Psychological examination of children of preschool - primary school age: Texts and a manual]. Moscow, UMK Psihologiya, 220-232.

Dmitriev, A.A., Verkhoturova, N. Yu. (2013). K probleme upravleniia ehmotsional'nym reagirovaniem uchashchikhsia mladshego shkol'nogo vozrasta s narusheniem intellektual'nogo razvitiia [On the problem of managing emotional responses of primary school pupils with impaired intellectual development]. In Vestnik Rossiiskogo universiteta druzhby narodov: nauchnyi zhurnal. Seriia: Psikhologiia i pedagogika [The Peoples' Friendship University of Russia Bulletin: Scientific journal. Pedagogy and Psychology Series], 1, 124-129.

Dmitriev, A.A., Verkhoturova, N. Yu. (2018). Emoctsonal'noe reagirovanie: fenomenologiia, strukturno-komponentnyi sostav, problemy i perspektivy issledovaniia [Emotional response: phenomenology, structural and component composition, problems and prospects of research]. In Sibirskii pedagogicheskii zhurnal: nauchno-prakticheskoe izdanie [Siberian Pedagogical Journal: Scientific Periodical], 3, 90-96.

Dmitrieva, S.A., Verkhoturova, N. Yu. (2013). Izuchenie psihologicheskikh simptomokompleksov u detei-sirot s zaderzhkoi psikhicheskogo razvitiia $\mathrm{v}$ protsesse otsenki ikh emotsional'noi kompetentnosti [The study of psychological symptom complexes of orphans with mental retardation in the process of assessing their emotional competence]. In Special'noe obrazovanie: nauchno-metodicheskii zhurnal [Special education: scientific and methodical journal], 3, 41-47.

Garro, A. (ed.). (2016). Early Childhood Assessment in School and Clinical Child Psychology. In Science+Business Media New York. Springer: NY. DOI: 10.1007/978-1-4939-6349-2.

Harris, P. L. Children and emotion (1989). The Development of Psychological understanding. Oxford, England, Basil Blackwell, 243 p.

Lafrene, P. (2004). Emotsional'noe razvitie detei i podrostkov [Emotional development of children and adolescents]. Saint Petersburg, Prime-EVROZNAK, 256 p.

Lebedinsky, V.V. (2003). Narushenie psikhicheskogo razvitiia $v$ detskom vozraste [Mental development disorders in childhood]. Moscow, Akademia, $144 \mathrm{p}$.

Lisova, N.A., Shilov, S.N. (2017). Osobennosti temperamenta i volevoi samoreguliatsii u studentov sportivnogo i gumanitarnogo profilei obucheniia [Features of temperament and discretionary self-regulation among students who study sports and humanities]. In Vestnik Novosibirskogo gosudarstvennogo pedagogicheskogo universiteta [Bulletin of the Novosibirsk State Pedagogical University], 7 (3), 72-88. DOI: 10.15293/2226-3365.1703.05.

Lubovsky, V.I., Valiavko, S.M. (ed.). (2009). Spetsial'naia psikhologiia: uchebnik [Special psychology: textbook]. Moscow, Akademia, 553 p.

Petrova, V.G., Beliakova I.V. (2002). Psikhologiia umstvenno otstalykh shkol'nikov [Psychology of mentally retarded schoolchildren]. Moscow, Akademia, $160 \mathrm{p}$.

Pleshakova, M.V., Nugaeva, O.G. (2011). Osobennosti graficheskoi ekspressii u podrostkov s liogkoi stepen'iu umstvennoi otstalosti [Features of graphic expression in adolescents with mild mental retardation]. In Mir nauki, kul'tury, obrazovaniia: nauchnyi mezhdunarodnyi zhurnal [The World of science, culture, education: international scientific journal], 5 (30), 136-140.

Rubinstein, S. Ya. (1986). Psikhologiia umstvenno otstalogo shkol'nika [The psychology of the mentally retarded pupil]. Moscow, Prosveshchenie, $192 \mathrm{p}$.

Savchenkov, Yu.I., Shilov, S.N., Bardetskaya, Ya.V. (2017). Osobennosti chert i struktury temperamenta u iunoshei i devushek-predstavitelei narodov Kavkaza (na primere studentov vuzov g. Krasnoiarska) [Features and structure of temperament of young men and girls - representatives of the Caucasusian peoples (on the example of students of Krasnoyarsk universities)]. In Zhurnal medicobiologicheskih issledovanii [Journal of Biomedical Research], 5 (2), 13-20. DOI: 10.17238/issn25421298.2017.5.2.13.

Schwanzara J. (1978). Diagnostika psihicheskogo razvitiya [Diagnosis of Mental Development]. Prague, Avicenum, 388 p. 
Semenova, E.V. (2008). Psihologicheskie osobennosti ehmotsional'nykh sostoianii shkol'nikov s umerennoi i tiazhioloi umstvennoi otstalost'iu [Psychological features of emotional states of schoolchildren with moderate and severe mental retardation]. In Vestnik Cherepoveckogo gosudarstvennogo universiteta: nauchnyi zhurnal [Bulletin of Cherepovets State University: Scientific Journal], 3, 108-118.

Sroufe, L.A. (1996). Emotional development: The organization of emotional life in early years. Cambridge, England, Cambridge University Press, 263 p.

Shapovalova, O.E. (2005). Osobennosti ehmotsional'nogo razvitiia umstvenno otstalyh shkol'nikov [Features of the emotional development of mentally retarded schoolchildren]. Moscow, MPSU, $183 \mathrm{p}$.

Shul'ga, T.I. (2012). Emotsional'no-volevoi komponent psikhologicheskoi gotovnosti k obucheniiu shkol'nikov [Emotional-discretionary component of psychological readiness of schoolchildren to learn]. In Vestnik Moskovskogo gosudarstvennogo oblastnogo universiteta. Seriia "Psihologicheskie nauki" [Bulletin of the Moscow State Regional University. Psychological Sciences Series], 1, 60-66.

Uruntaeva G. A., Afon'kina Yu.A. (1998). Praktikum po doshkol'noj psihologii [Workshop on Preschool Psychology]. Moscow, Academia, 293 p.

Verkhoturova, N. Yu. (2012). K probleme opredeleniia struktury i mekhanizmov ehmotsional'nogo reagirovaniia [On the problem of defining the structure and mechanisms of emotional response]. In Sibirskii pedagogicheskii zhurnal: nauchno-prakticheskoe izdanie [Siberian Pedagogical Journal: Scientific Periodical], $5,150-154$

Verkhoturova N. Yu., Abdulkin V.V. (2016). Characteristic and specifics of the modelling method in emotional responsivity correction of the pupils with the intellectual development disorders. In SGEM International Multidisciplinary Scientific Conference on Social sciences and Arts, 1 (1), 623-632.

\title{
Изучение и оценка эмоционально-личностных тенденций и поведенческого репертуара эмоционального реагирования учащихся младшего школьного возраста с нарушением интеллекта
}

\section{Н.Ю. Верхотурова, Я.В. Бардецкая}

Красноярский государственный педагогический университет им. В.П. Астафьева

Российская Федерачия, Красноярск

\begin{abstract}
Аннотация. В статье поднимается недостаточно исследованная, но актуальная проблема необходимости своевременного изучения и оценки эмоциональноличностных тенденций и поведенческого репертуара эмоционального реагирования учащихся младшего школьного возраста с нарушением интеллектуального развития. Решение ключевых вопросов, связанных с улучшением процессов социализации и социальной адаптации данного контингента школьников в условиях современного общества, не может рассматриваться вне контекста проблемы изучения и коррекции эмоциональной регуляции их поведения. Исследуемой категории школьников свойственны существенное отставание в развитии эмоционального реагирования, узость диапазона переживаний, частое несоответствие эмоциональных реакций внешним воздействиям по силе, интенсивности и содержанию, ограниченность интерпретации чувственного материала, которые приводят к неполноценному восприятию эмоциональных реакций других людей и не всегда адекватному и дифференцированному выражению собственных эмоциональных реакций
\end{abstract}


социально приемлемыми способами. Все это провоцирует сложности во взаимоотношениях учащихся с нарушением интеллектуального развития между собой и с окружающими взрослыми, создаёт серьезные барьеры в их обучении и воспитании, опосредует возникновение отклонений в поведении различного порядка, приводит к трудностям социальной адаптации и социализации.

В статье описывается организация реализуемого исследования, раскрываются основные компоненты, технологические параметры, этапы изучения эмоциональноличностных тенденций и поведенческого репертуара эмоционального реагирования учащихся младшего школьного возраста с нарушением интеллектуального развития. Модель исследования раскрывается посредством последовательно реализуемых диагностических блоков, направленных на изучение и оценку доминирующих в поведении учащихся эмоциональных реакций, экспрессивной выразительности и регуляции эмоционального реагирования, а также на изучение и оценку когнитивно-перцептивного содержания эмоционального реагирования учащихся младшего школьного возраста с нарушением интеллектуального развития.

На основании реализуемого исследования описываются специфические особенности эмоционально-личностных тенденций и поведенческого репертуара эмоционального реагирования учащихся младшего школьного возраста с нарушением интеллектуального развития, которые не только возможно, но и необходимо своевременно подвергать психолого-педагогической коррекции с целью улучшения процессов социализации и интеграции изучаемого контингента школьников в современном обществе.

Ключевые слова: эмоциональное реагирование, эмоциональные реакции, эмоционально-личностные тенденции, поведенческий репертуар, компоненты эмоционального реагирования, учащиеся с нарушением интеллектуального развития.

Научная специальность: 19.00.10 - коррекционная психология. 